リンパ節転移を契機に発見された回腸カルチノイド腫瘍の 1 例

埼玉医科大学総合医療センター外科, 同 病理*, 鶴瀬病院外科**

傍 島 潤 石 田 秀行 横 山 勝

林 洋一都築 信太郎 橋 本大定

安達 章子* 系山進 次* 権田 剛**

\title{
A Case of Ileal Carcinoid Tumor Diagnosed by Its Lymph Node Metastases
}

\author{
Jun SOBAJIMA, Hideyuki ISHIDA, Masaru YOKOYAMA, \\ Youichi HAYASHI, Shintaro TSUZUKI, Daijo HASHIMOTO, \\ Akiko ADACHI*, Shinji ITOYAMA* and Tsuyoshi GONDA** \\ Departments of Surgery and Pathology*, Medical Center, Saitama Medical School \\ ${ }^{* *}$ Department of Surgery, Tsuruse Hospital
}

\begin{abstract}
本邦では空・回腸に発生するカルチノイドの発生は稀である。腸間膜リンバ節転移が診断の契機となった，径 $13 \mathrm{~mm}$ 大の回腸カルチノイドの稀な 1 例を経験したので報告する。症例は 55 歳, 男性。腹痛の精查目的で入院。腹 部CTで腸間膜に約 $4 \mathrm{~cm}$ の造影される腫瘤性病変を認めた。上腸間膜動脈造影では回腸間膜領域に腫瘍濃染像を 認めたが, 小腸造影では明らかな異常を認めなかった。腸間膜腫瘍を疑い, 手術を施行したところ, 回腸腸間膜 内に約 $4 \mathrm{~cm}$ 腫瘍と, 終末回腸から約 $60 \mathrm{~cm}$ の部位の回腸に引きつれを認めたため, これを含めた回腸約 $50 \mathrm{~cm}$ その範囲の腸間膜とともに切除した。腸間膜腫瑒の術中迅速組織検査でカルチノイド腫瘍のリンパ節転移と診断 された。回腸のひきつれた部位には径 $13 \mathrm{~mm} の$ 粘膜下腫瘍を認め, 組織学的に好銀染色陽性であり, 最終的に回腸 カルチノイドと診断した。術後11カ月を経過した現在, 再発の徴候を認めていない。
\end{abstract}

索引用語：カルチノイド腫瘍 (carcinoid tumor), 回腸 (ileum), リンパ節転移 (lymph node metastasis)

\section{はじめに}

消化管カルチノイドのなかでも空腸，回腸原発 のものは稀である。今回, 腸間膜リンパ節転移を 契機に診断された回腸原発カルチノイドの 1 例を 経験したので，文献的考察を加えて報告する。

\section{症例}

患 者：55歳, 男性。

主 訴：腹痛。

既往歴：十二指腸潰瘍，高血圧。

家族歴：特記事項なし。
現病歴：2002年 8 月 20 日, 間欠的腹痛が出現し たため，近医を受診した。同部に圧痛を認めたた め, 精査ため入院したところ, 白血球の上昇を認 めたほか, 腹部CT検査で腹腔内腫瘍が疑われた。 手術目的で当科に紹介入院となった。

来院時現症: 血圧 $122 / 76 \mathrm{mmHg}$, 体温 $36.0^{\circ} \mathrm{C}$ 。 腹部は臍周囲に限局的な圧痛を認めた。いままで にカルチノイド症候群を疑わせるような顔面の皮 膚紅潮，下痢はみられなかった。

入院時血液生化学検查: WBC $14,100 \times 10^{3} \mu$ l, CRP $11.0 \mathrm{mg} / \mathrm{dl}$ であり, 腫痬マーカーはCEA $3.4 \mathrm{ng} / \mathrm{ml}(1.0 \sim 6.7 \mathrm{ng} / \mathrm{ml})$, CA19-9 $26 \mathrm{U} / \mathrm{ml}(37$ 
Table 1 Laboratory data

\begin{tabular}{|l|l|}
\hline WBC & $14,100 \times 10^{3} / \mu \mathrm{l}$ \\
\hline $\mathrm{Hb}$ & $13 \mathrm{~g} / \mathrm{dl}$ \\
\hline $\mathrm{Ht}$ & $38.4 \%$ \\
\hline Plate & $28.8 \times 10^{3} / \mu \mathrm{l}$ \\
\hline APTT & $31.9 \mathrm{sec}$ \\
\hline PT & $90 \%$ \\
\hline T.P. & $6.7 \mathrm{~g} / \mathrm{dll}$ \\
\hline Alb & $3.9 \mathrm{~g} / \mathrm{dl}$ \\
\hline AST & $16 \mathrm{IU} / \mathrm{l}$ \\
\hline ALT & $11 \mathrm{IU} / \mathrm{l}$ \\
\hline LDH & $152 \mathrm{IU} / \mathrm{l}$ \\
\hline$r$-GDP & $30 \mathrm{IU} / \mathrm{l}$ \\
\hline CRP & $11 \mathrm{mg} / \mathrm{dl}$ \\
\hline CEA & $3.4 \mathrm{ng} / \mathrm{dll}(1.0 \sim 6.7)$ \\
\hline CA19-9 & $26 \mathrm{U} / \mathrm{ml}(<37)$ \\
\hline $5-H I A A$ (urine) & $2.9 \mathrm{mg} / \mathrm{dl}(1.0 \sim 6.0)$ \\
\hline
\end{tabular}

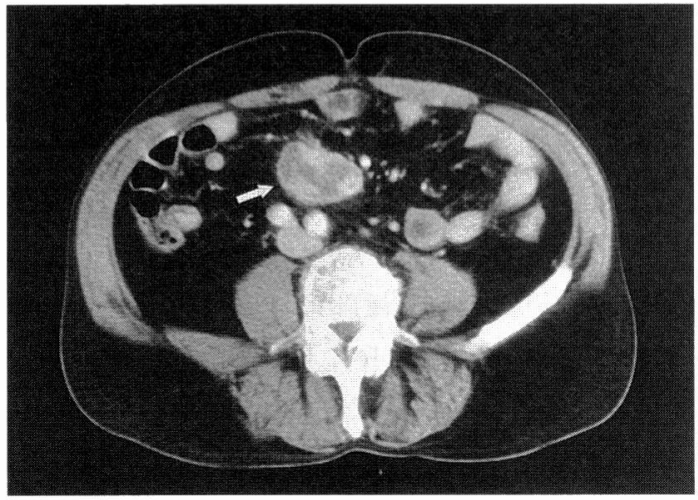

Fig. 1 Abdominal computed tomography shows enhanced mass lesion $4 \mathrm{~cm}$ in diameter in the mesentery.

$\mathrm{U} / \mathrm{ml}$ 以下) と基準值範囲内であった。また，手術 前日の尿中5-hydroxyindole (5-HIAA) も2.9mg/ 1(1.0〜6.0mg/l) と基準值範囲内であった (Table 1)。

腹部CT検査：腸間膜に造影剂でenhanceされ る $4 \mathrm{~cm}$ 大のmass lesionを認めた（Fig. 1)。

腹部MRI検查：腸間膜に約 $4 \mathrm{~cm} の \mathrm{~T} 1$ 強調画 像, T2強調画像共に筋肉とほぼ同等の信号強度を

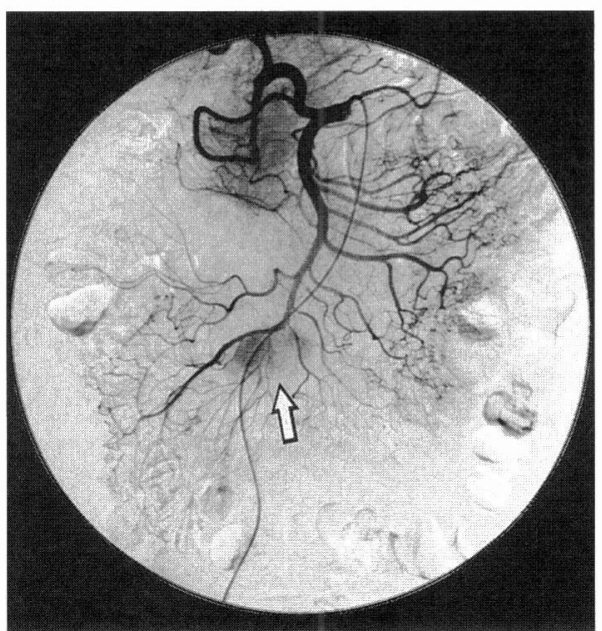

Fig. 2 Superior mesenteric arteriography shows hypervascular mass (arrow) feeded from the ileal artery.

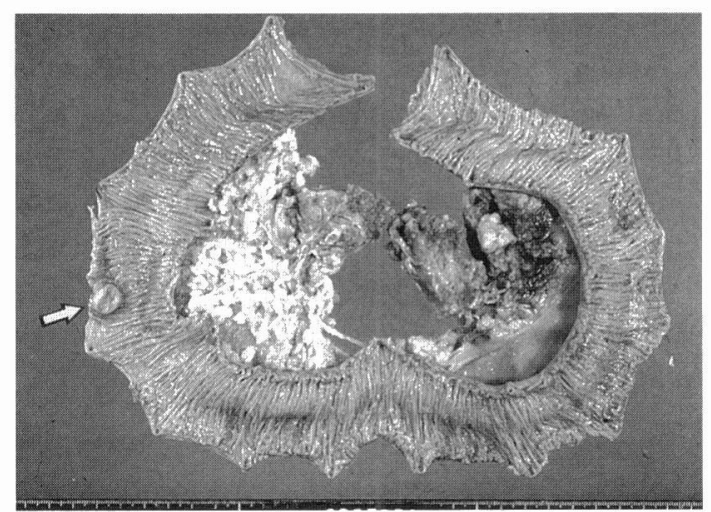

Fig.3 Resected specimen shows submucosal tumor in the ileum $13 \mathrm{~mm}$ in diameter (arrow).

示し，造影にて辺縁を優位にやや不均一な造影剤 増強効果を示古腫瘤を認めた。

腹部血管撮影：上腸間膜動脈造影では回腸間膜 領域に腸管と一致しない腫瘍濃染像を認めた

(Fig. 2)。

小腸造影：明らかな腫瘤影を認めなかった。そ の他，上部消化管内視鏡検査および注腸検査では 特に異常は認めなかった。

以上の所見より，小腸腸間膜腫瘍を疑い, 2002 年 9 月 17 日手術を施行した。

術中所見：腹水はなく，腸管のねじれや屈曲は 認めなかった。腸間膜の線維化や牽縮は認めなか 

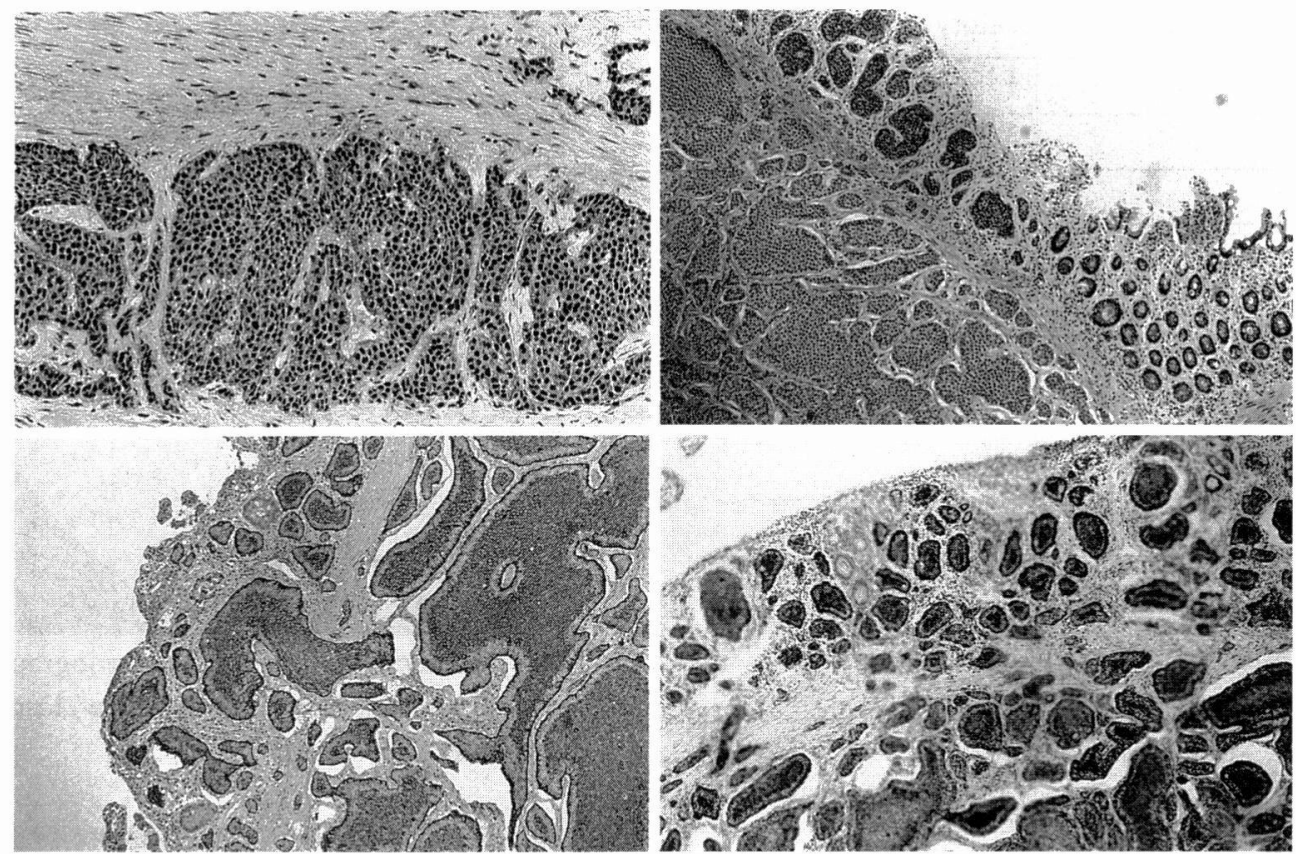

Fig. 4 : a) Frozen section showing proliferation of tumor cells with small and round nuclei in the removed lymph node $(\times 1,000)$.

b) There is a proliferation of tumor cells with small and round nuclei. HE staining $(\times 250)$.

c) Immunohistochemical examination showing tumor cells positive for Grimelius staining ( $X$ 250).

d) Silver stanining study (Fontana-Masson method) demonstrating that tumor cells are argetaffin positive $(\times 500)$.

つた。回腸腸間膜内に約 $4 \mathrm{~cm}$ 大の硬い腫瘍性病変 を認めた。術中迅速組織検査で腸間膜リンパ節内 に小型，類円形で均質な核を持つ大きさの揃った 腫瘍細胞が, 索状, シー卜状に増殖しており, 細 胞形態からカルチノイドのリンパ節転移と䛦断さ れた $($ Fig. 4a)。小腸を全長にわたり検索したとこ ろ, 終末回腸から約 $60 \mathrm{~cm}$ の部位の回腸に引きつれ を認めた。腹膜播種, 肝転移は認めなかった。ひ きつれた部位を含めた回腸約 $50 \mathrm{~cm}$ を腸間膜内の 腫瘍性病変と中枢側のリンパ節を含め, 上腸間動 脈からの分岐部の回腸動脈まで合併切除し, 回腸 は端々吻合にて再建した。

摘出標本：引きつれた部位には径 $13 \mathrm{~mm}$ の黄色 平皿状で隆起性の粘膜下腫瘍を認めた (Fig. 3)。

病理組織学的所見: HE染色では小型類円形核 の大きさの揃った腫瘍細胞が島状に増殖していた (曾我分類 $\mathrm{A}$ 型 ${ }^{1)}$ )。腫瘍細胞は筋層間を分け入る
ように浸潤し, 漿膜下層まで達していた（Fig. $4 \mathrm{~b})$ 。免疫組織染色では腫瘍細胞は好銀顆粒陽性 (Grimelius法) (Fig. 4c), Fontana-Masson法に よる銀還元性反応も陽性であり (Fig. 4d), 前腸型 カルチノイドと考えられた。リンパ管侵襲, 神経 周囲浸潤，静脈侵襲が認められた。腸間膜リンパ 節は検索された全てに転移が認められた。

術後経過は良好で10病日に退院した。術後 9 力 月目の画像診断で, リンパ節転移・肝転移など, 再発の所見を認めていない。

\section{考察}

消化管に発生するカルチノイドの好発部位は欧 米では虫垂, 小腸, 直腸の順に多いとされている

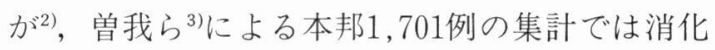
器系臓器の発生頻度は, 直腸 (36.1\%), 胃 (26.7 $\%)$, 十二指腸 (14.9\%), 虫垂 $(7.4 \%)$, 小腸 $(3.8$ 
\%）の順であり，十二指腸を除く小腸の発生は稀 である。消化器原発カルチノイド全体の転移率が $27.8 \%$ であるのに对し，回腸カルチノイドの転移 率は $53.2 \%$ とされ, 消化器原発カルチノイドの中 では比較的高率である。回腸カルチノイドの転移 藏器は他の部位と同様, リンパ節 $(72.0 \%)$, 肝 (52.0\%)などが多い。また名取ら゙)による小腸力 ルチノイド63例の腫瘍径の検討では, $1 \mathrm{~cm}$ 以下が 6.7\%, $1 \mathrm{~cm}$ か $2 \mathrm{~cm} 335.6 \%, 2 \mathrm{~cm}$ 以上が 57.8

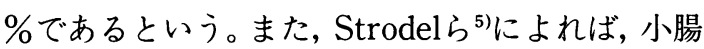
カルチノイドの腫瘍径別のリンパ節転移率は, 腫 瘍径 $1 \mathrm{~cm}$ 以下が $29 \% ， 1 \mathrm{~cm}$ か $2 \mathrm{~cm} 6$ 61\%，2 $\mathrm{cm}$ 以上が $82 \%$ と小腫瘤でも比較的高い転移率で あることが指摘されている。以上から，今回の症 例のような大きさ $13 \mathrm{~mm}$ の回腸カルチノイドがリ ンパ節転移をきたすこと自体は，それほど稀なこ とではないと思われる。しかしながら，原発巣よ り転移リンパ節のほうがはるかに大きく，そのリ ンパ節転移が診断の契機となった点は興味深く, 本邦報告小腸カルチノイドのなかで，類似した症 例は見いだすことはできなかった（医学中央雑誌 1984年〜2003年)。

小腸カルチノイドの術前診断率は $4.8 \%$ と低 (2)。回腸末端部が好発部位で, そのような部位で は大腸内視鏡での発見が十分可能であるが，今回 の症例のように回腸末端からかなり離れた部位に 原発巣がある場合には，小腸造影や血管造影で診 断されうる。特に，小腸造影では回腸の院影欠損 と腸管走行の急激な変化は重要な所見とされてい るが，今回の症例ではretrospectiveに検討してみ ても，そのような所見はみられなかった。また， 腹部血管撮影では血管走行の不整や, hypervascularな腫瘍として描出されることがある。また， 今回の症例のように転移リンパ節が大きくなり， とらえられることもある。しかしながらこれらの 所見はカルチノイドに特異的な所見ではない。小 腸カルチノイドでは，腸間膜への浸潤やリンパ節 転移により，腸間膜の牽縮がおきると，CTやMRI で腫瘍から腸管に放射状に向かう線状構造を認 め，血管造影では腸間膜内の動脈が放射状の走行 をとることが特有の所見といわれている6)。この 線状構造物は, 腸間膜内の神経血管束であること
が組織学的に確認されている7)。今回の症例では そのような所見は認めなかった。

今回の症例も小腸カルチノイドに最も頻度が高 い腹痛を主訴にしていた。カルチノイド特有の腸 間膜の举縮が腹痛をもたらすことが指摘されてい るが，今回の症例では画像上，あるいは組織学的 検索のいずれにおいても，腸管膜の牽縮の原因に 合致する所見は得られず，腹痛は単なる偶然であ った可能性も否定できない。

今回の症例では原発巣近傍ではなく，かなり中 枢側（上腸間膜動脈側）のリンパ節に転移があり, 今後大動脈周囲などのリンパ節再発や肝再発を想 定して慎重な経過観察が必要と考えている。再発 予防に明らかに有効な補助化学療法はないので, いまのところ画像上の再発チェックを 3 力月おき に行っている。

\section{結 語}

腸間膜リンパ節転移を契機に診断された回腸原 発カルチノイド $(13 \mathrm{~mm})$ の 1 例を経験したので, 文献的考察を加えて報告した。

本稿の要旨は第28回日本外科系連合学会学術集会 （2003年 6 月，東京）で発表した。

\section{参考文献}

1) Soga J, Tazawa $K$ : Pathologic analysis ofcarcinoids. Histologic Reevaluation of 62 cases. Cancer 28: 990-998, 1971

2) 牧本伸一郎, 新保雅也, 仲本 剛他 : 腹腔内腫瘤 として発見された回腸カルチノイドの1例.日消 外会誌33：1930-1934，2000

3）曽我 淳, 鈴木 力：カルチノイドとカルチノイ ド症候群。日臨 $15 ： 207-221,1993$

4）名取志保, 長田俊一, 亀田久仁郎他：空腸カルチ ノイド腫瘍の 1 例。日消外会誌 $36: 34-39,2003$

5) Strodel WE, Talpos G, Eckhauser F, et al: Surgical therapy for small-bowel carcinoid tumors. Arch Surg 118:391-397, 1983

6) 田村保明, 加藤法導, 谷口由輝他：腸間膜牽縮を 伴った回腸カルチノイドの一例. 日消病会誌87： 2404-2409, 1990

7）上田順彦, 根塚秀昭, 山本精一他：腸間膜牽縮を 伴った回腸カルチノイドの一例. 日消外会誌 34 ： 1765-1769, 2001 